\title{
Prenatal Diagnosis and Management of Conjoined Fetuses
}

\author{
Apostolos Athanasiadis, Themistoklis Mikos, Menelaos Zafrakas \\ Department of Obstetrics and Gynecology, Aristotle University of Thessaloniki, Greece.
}

\begin{abstract}
Conjoined twins have an estimated incidence of one in 50,000 to one in 100,000 births. The first cases of prenatal diagnosis of conjoined twins using B-mode ultrasound were reported in the 1970s, followed by prenatal real-time ultrasonographic diagnosis shortly thereafter. Since then, real-time ultrasound has been the most reliable method in establishing prenatal diagnosis of conjoined twins and in detecting associated anomalies. Moreover, recent improvements in real-time ultrasound technology — in some cases coupled with use of Magnetic Resonance Imaging (MRI) — have made early diagnosis of conjoined fetuses in the first trimester possible. Prenatal diagnosis of conjoined fetuses is considered essential for further management. Parents need detailed counseling in order to decide among various management options, which include the following: (a) pregnancy continuation and scheduled neonatal surgery, (b) termination of pregnancy, and (c) multifetal pregnancy reduction or selective fetocide in cases of high-order multifetal pregnancies with a component of conjoined fetuses. An interdisciplinary medical team, involving obstetricians, neonatologists, pediatric surgeons and anesthetists, should carefully approach and assist parents in their decisions. In special cases, additional consultation may be given by other specialists, even from specialized centers in other countries, depending on the area of conjunction, the involvement of other organ systems, and the presence of associated anomalies.
\end{abstract}

Key words: Conjoined twins, conjoined triplets, prenatal diagnosis, magnetic resonance imaging, surgical separation, fetal echocardiography.

\section{INTRODUCTION}

Though an unusual phenomenon, conjoined fetuses have always drawn a disproportionately high degree of attention and interest from scientists and general public. This is apparently due to the intriguing processes involved in the pathogenesis of conjoined fetuses, the rare and even unique patterns of conjunction leading to complexity in management and surgical separation in individual cases, and a series of ethical questions coupled with a variety of emotional reactions and interactions between parents, relatives and health care providers. In recent years, the advent of real-time ultrasound and other novel imaging techniques have made early prenatal diagnosis of conjoined fetuses possible, enabling specialists and parents to decide whether pregnancy should continue or not, and plan well in advance prenatal management, timing of delivery and immediate and long-term postnatal management, based on future quality of life and survival issues.

\section{HISTORICAL PERSPECTIVE}

Fetal conjunction usually involves two fetuses in a twin pregnancy. The term "Siamese twins" is often used for conjoined twins, since the most famous case of conjoined twins surviving to adulthood in modern times were born in Siam (today's Thailand). This case was well known to the general public at their time, owing to numerous photographs published in newspapers around the world. Eng and Chang Bunker, were born in Thailand in 1811, grew up together, married two sisters, raised 21 children, and died both at the age of 69 , a few hours apart from another, without ever being separated. ${ }^{1}$ Long before this case and the invention of photography, in $1100 \mathrm{AD}$ lived the Bidenden twins, who survived until the age of 34, probably representing the oldest well-documented case of conjoined twins surviving to adult life. ${ }^{1}$

Until the invention of diagnostic imaging, starting with the use of diagnostic X-rays in the early 20th century, diagnosis of conjoined twins was possible only during labor. Labor arrest was the first sign in such cases, and sacrifice of one or both fetuses was often necessary in order to accomplish delivery. ${ }^{2,3}$ The first report of prenatal diagnosis of conjoined twins using X-rays was published in 1934, while specific radiodiagnostic criteria were first described in $1950 .^{2,4,5}$ Even then however, prenatal diagnosis of conjoined twins could be missed, due to various possible factors: Absence of bone connections between twins, change of twins' position in utero, and the fact that the investigator was usually not considering the possibility of conjoined twins. ${ }^{2,6}$

The first cases of prenatal diagnosis of conjoined twins using B-mode ultrasound were reported in the 1970's, followed by prenatal real-time ultrasonographic diagnosis shortly thereafter. ${ }^{2,7-12}$ Since then, real-time ultrasound has been the most reliable method in establishing prenatal diagnosis of 
conjoined twins and in detecting associated anomalies. Moreover, recent improvements in real-time ultrasound technology - in some cases coupled with use of Magnetic Resonance Imaging (MRI) — have made early diagnosis of conjoined fetuses in the first trimester possible, ${ }^{13-17}$ and uncovered a "hidden mortality" of conjoined twins, because of the increase in their detection rates. ${ }^{2,18}$ Furthermore, prenatal diagnosis of more complex, not previously documented cases of conjoined fetuses in triplet pregnancies has been recently made possible with real-time ultrasound: A case of conjoined triplets, i.e. three fetuses all joined together ${ }^{19}$ and cases of triplet pregnancies containing a pair of conjoined twins, i.e. two conjoined fetuses with a third non-involved co-triplet comprising a triplet pregnancy. ${ }^{20,21}$

\section{INCIDENCE AND CLASSIFICATION}

Conjoined twins have an estimated incidence of one in 50,000 to one in 100,000 births. ${ }^{22-24}$ Incidence appears to be independent of maternal age, race, parity, and heredity. Conjoined twins are generally classified according to the site at which they are joined into: (i) omphalopagus (from the Greek word "omphalos" for umbilicus), (ii) thoracopagus (chest) (Fig. 1), (iii) cephalopagus (head), (iv) ischiopagus (hip), (v) craniopagus (cranium), (vi) rachipagus (spine), (vii) pygopagus (rump), and 8) parapagus (side). The terms "brachius" (upper limb), "pus" (lower limb) and "cephalus" (head), and the numerals di-, tri-, and tetra- (two, three and four respectively) are also used accordingly (Table 1). ${ }^{19,25}$ Omphalopagus and thoracopagus fetuses are joined in the trunk, but they differ in that the former have two separate hearts, while the latter share a common heart. ${ }^{25}$ Omphalopagus are reportedly not as rare (0.5-18\%) as craniopagus conjoined twins (1-5\%). ${ }^{2,25}$

Assessment of the conjunction type is essential for the identification of shared organs and associated anomalies of conjoined fetuses. Thoracopagus twins always share a common liver, a common heart in 75 percent with a common pericardium in 90 percent, and a common gastrointestinal tract in 50 percent

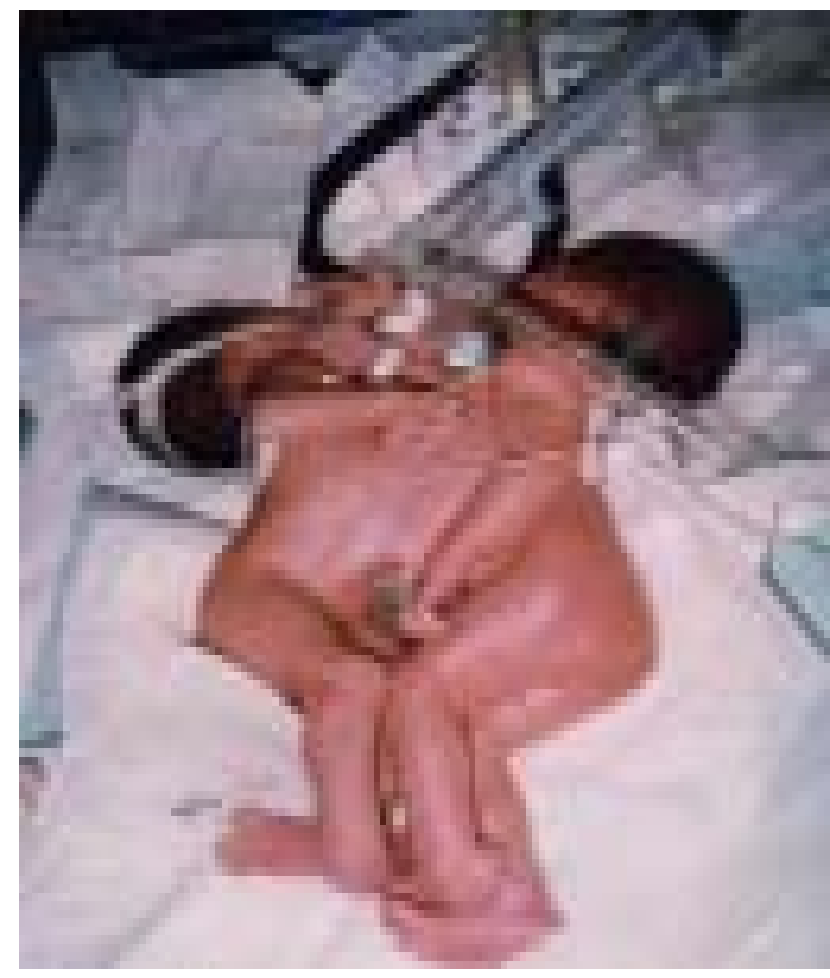

Fig. 1: Thoracopagus conjoined twins (Reprinted after authors permission from: Athanasiadis et al. Prenatal management and postnatal separation of omphalopagus and craniopagus conjoined twins. Gynecol Obstet Invest;in press)

of cases. Omphalopagus and xiphopagus twins share a common liver in 81 percent of cases, have associated gastrointestinal tract anomalies (omphalocele, common distal ileum and/or Meckel's diverticulum) in 33 percent, and congenital heart disease in 25 percent of cases. Pygopagus twins always share a common sacrum and coccyx, and they usually have a common rectum, bladder and urethra. Ischiopagus twins frequently have associated anomalies of the lower spine, while the lower extremities opposite to the conjunction area are frequently rudimentary. ${ }^{2}$ In addition, ischiopagus tetrabrachius tripus have

Table 1: Classification system of conjoined twins

\begin{tabular}{|c|c|c|c|c|c|c|c|c|c|}
\hline \multicolumn{5}{|l|}{ Type } & \multicolumn{5}{|c|}{ Union / Fusion site } \\
\hline & Face & Cranium & Thorax & Heart & Abdomen & Pelvis & Spine & Arms & Legs \\
\hline Cephalopagus & + & - & + & + & + & - & - & - & - \\
\hline Thoracopagus & - & - & + & + & + & - & - & - & - \\
\hline Omphalopagus & - & - & + & - & + & - & - & - & - \\
\hline Ischiopagus & - & - & - & - & + & + & - & - & - \\
\hline Parapagus & $+1-$ & $+1-$ & $+1-$ & $+1-$ & $+1-$ & + & - & $+1-$ & $+1-$ \\
\hline Craniopagus & - & + & - & - & - & - & - & - & - \\
\hline Pygopagus & - & - & - & - & - & + & $+1-$ & - & - \\
\hline Rachipagus & - & - & - & - & - & $+1-$ & + & - & - \\
\hline
\end{tabular}


two distinct hearts, while parapagus tetrabrachius tripus share a common heart. 2,25

Parasites usually appear after demise of one twin possibly originally defective. The supernumerary structures (the parasite) survive and remain attached to and vascularized by the remaining usually normal twin (the autosite). The most frequent organs found in the parasite are the limbs. ${ }^{25}$

\section{ETIOPATHOGENESIS}

The etiopathogenesis of conjoined fetuses is unclear. No inheritance pattern seems to exist. The inciting factor(s)environmental, genetic or both-leading to conjunction of fetuses are not known. Pregnancies with conjoined fetuses demonstrate a strong sex predilection: 70 to 95 percent of conjoined fetuses are female. ${ }^{26}$ Based on this association, it has been hypothesized that the underlying molecular mechanism might be the inactivation of chromosome X. Normally, in somatic, diploid cells of female individuals one of the two $\mathrm{X}$ chromosomes is inactivated, and this physiologic phenomenon seems to occur randomly. Molecular analyses however, failed to show any association between chromosome $\mathrm{X}$ inactivation and conjoined fetuses. ${ }^{27}$ On the other hand, epigenetic or even genetic changes should be present at least at the interface of fetal conjunction, and this possibility could be answered by future studies.

From an embryological point of view, there are two opposing theories concerning the pathogenesis of conjoined fetuses: fission vs. fusion. ${ }^{25,28}$ According to the fission theory, division of the inner cell mass between the 13th and the 15th day after fertilization results in conjoined embryos. To put things into context, it is generally accepted that division of the inner cell mass during the first 72 hours after fertilization leads to dichorionic-diamniotic, between days 4 and 8 to monochorionicdiamniotic, and between days 8 and 13 to monochorionicmonoamniotic multiple pregnancies. ${ }^{29,30}$

According to the fusion theory, the embryos fuse in the early embryonic period, after a short period in the first hours or days after fertilization in which they are independent from one another. This theory is supported by the fact that conjoined embryos and fetuses are united at sites where the surface ectoderm is absent or pre-programmed to become disrupted or fused. ${ }^{25}$ A more detailed concept of the fusion theory, also referred to as the "spherical theory", ${ }^{25}$ suggests that the monoovular embryonic discs lie adjacent to one another, like floating on the surface of a sphere (the yolk sac) or in the inside of another sphere (the amniotic cavity), and gradually unite. In any case, the pathophysiological processes involved in embryonic conjunction seem to take place in the very early first trimester, in a period in which embryos are invisible with current techniques: later than the blastocyst stage, when embryos can be easily visualized with a microscope before implantation in the setting of in vitro fertilization and too early to be visualized with diagnostic ultrasound.

\section{PRENATAL DIAGNOSIS}

Prenatal diagnosis of conjoined fetuses is considered essential for further management. Parents need detailed counseling in order to decide among various management options, which include the following: (a) pregnancy continuation and scheduled neonatal surgery, (b) termination of pregnancy, and (c) multifetal pregnancy reduction or selective fetocide in cases of high-order multifetal pregnancies with a component of conjoined fetuses. ${ }^{31}$

Diagnosis of conjoined fetuses should be suspected whenever a monochorionic-monoamniotic pregnancy is detected. Sonographic identification of distinct placentae or intervening amniotic membrane(s) rules out fetal conjunction. ${ }^{2}$ It has been reported that increased levels of alpha-fetoprotein are indicative of conjoined twins, ${ }^{32}$ but data regarding specificity and sensitivity of this biochemical marker for detection of conjoined fetuses are lacking. Possible ultrasound indicators of conjoined fetuses are polyhydramnios, which is fairly common in conjoined twins occurring in 50 to 76 percent, as well as the bi-breech and face-to-face presentation of twins. ${ }^{33,34}$ Ultrasound diagnosis of conjoined fetuses can sometimes be straightforward, particularly when fusion of fetal parts is sonographically clear. In any case, a careful approach is considered necessary in order to avoid misdiagnosis, and repeating sonographic investigations at least once is a rule that should be followed. ${ }^{2}$

Several cases of conjoined twins diagnosed ultrasonographically in the first trimester have been reported in the literature. ${ }^{13-17}$ Very early sonographic diagnosis of conjoined twins appears to add minimal practical information compared with detection at the 11 to 14 weeks' scan. Use of 3D imaging also does not appear to improve diagnosis of conjoined fetuses (Fig. 2). ${ }^{31}$ There have been however, cases of conjoined twins reported in the literature, which were specifically diagnosed with the use of 3D ultrasound. Three-dimensional ultrasound appears to have advantages in differentiating between twin reversed arterial perfusion sequence and epigastric heteropagous conjoined twins. $^{35}$

The mainstay in prenatal diagnosis of conjoined twins today is use of two-dimensional ultrasound enhanced by color-flow Doppler at the 11 to 14 week scan. Specific sonographic features indicative of conjoined fetuses have been proposed: (a) bifid appearance of the fetal pole in the first trimester; (b) absence of separating membrane(s) between fetuses; (c) non-separation of fetal bodies; this finding should persist and it should be always visualized at the same anatomic level; (d) detection of a variety of fetal anomalies; (e) finding more than three vessels in the umbilical cord; (f) sonographic evidence of fetal heads and bodies lying in the same plane; (g) unusual extension of the 


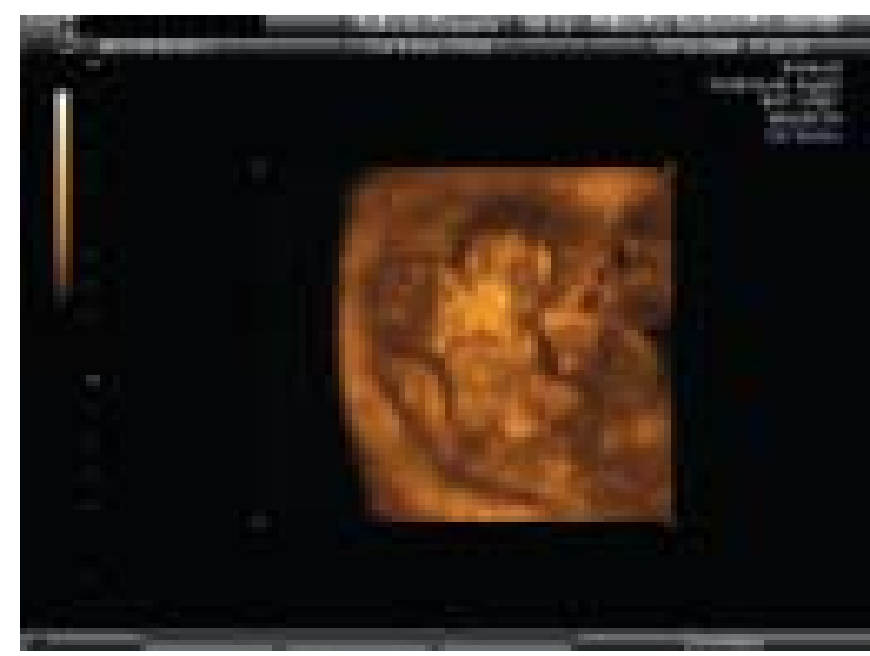

Fig. 2: 1st trimester prenatal diagnosis of thoracopagus conjoined twins with three-dimensional ultrasound

fetal spines; (h) unusual proximity of the fetal extremities; (i) the fetuses do not change position to one another after movement or manipulation or as time passes by. ${ }^{2}$

On the other hand, under certain circumstances diagnosis of conjoined fetuses may be missed or separate fetuses may be misdiagnosed as conjoined, since various sonographic signs may be misleading. Occasionally, the separating membrane between monochorionic twins is hard to visualize on ultrasound, giving transiently the false impression that fetal parts are contiguous. ${ }^{6}$ On the other hand, discordant presentation of fetuses in a multiple pregnancy does not necessarily exclude the diagnosis of conjoined fetuses, since rotation of the fetus(es) is possible, especially when the joining tissue bridge between them is small and pliable. Furthermore, in cases with extensive fetal conjunction, the sonographic appearance may mimic a singleton pregnancy, and thus attention should be given in order to identify duplication of any anatomical parts, including the brain, heart, liver, extremities and spine. ${ }^{2}$ In the third trimester, the ultrasound appearance of conjoined twins can be elusive, because when one head is engaged in the pelvis and the other is found higher, conjoined twins appear to be separate. ${ }^{6}$ Modern imaging modalities, such as 3D- and 4D-ultrasound, power Doppler, and fetal rapid MRI can be used in order to support the diagnosis, and exclude possible pitfalls in the sonographic diagnosis of conjoined fetuses.

The aim of the prenatal delineation of the type of fetal conjunction is to predict the immediate postnatal viability of the fetuses and viability of at least one of them after a potential surgical separation. This is important, since the overall mortality rate of conjoined twins has been reported to be as high as 28 percent prenatally, 54 percent immediately postnatally, while long-term survival rates are only about 18 percent. ${ }^{18}$ Separation of omphalopagus conjoined twins is reported to have success rates of approximately 80 percent. In contrast, separation of craniopagus twins is unlikely without long-term seqeulae. ${ }^{25}$

\section{PRENATAL SURVEILLANCE}

Accurate antenatal classification of conjoined fetuses allows early counseling of parents so that the options of pregnancy termination or near-term cesarean delivery in order to minimize maternal morbidity can be discussed. Defining prognosis prior to 24th week of gestation is important, since termination of pregnancy by the vaginal route is still feasible at this point. ${ }^{11,36,37}$ Prenatal evaluation and surveillance of conjoined fetuses includes ultrasonography, and MRI, with special attention to the fetal heart(s), preferably after 18 weeks' gestation, in order to determine the anatomy of shared organs and detect any associated anomalies. ${ }^{18}$ Serial sonograms in the late second trimester may be necessary in order to fully assess anatomic relationships and evaluate the effects of cross-circulation, mainly polyhydramnios and hydrops. ${ }^{38}$

While hemodynamic analysis of the umbilical artery (UA) with color-flow Doppler does not seem to add significant information in the antenatal detection of conjoined fetuses, it seems to help in the evaluation of fetal well-being. Effective application of serial Doppler velocimetry has been recently reported in a set of thoracopagus twins: Increasing UA maximum velocity led to decision for delivery at 27 th week due to fetal distress. ${ }^{39}$

According to previous reports, conjoined twins sharing a common heart will eventually succumb without surgical intervention within three months after delivery. ${ }^{40}$ Prenatal cardiac evaluation of thoracopagus and omphalopagus twins allows classification of conjoined fetuses into three groups: (a) those with a single pericardium containing two normal hearts (separable conjoined twins), (b) those with fixed ventricles (inseparable conjoined twins), and (c) fetuses with conjoined atria and separate ventricles. ${ }^{2,40}$ Conjoined six-chamber hearts are found frequently in thoracopagus twins and have never been separated successfully, while separation of twins with conjoined atria has been reported in only one case. ${ }^{41,42}$

Combined prenatal and postnatal echocardiography may accurately delineate cardiac fusion, intracardiac anatomy, and ventricular function in the majority of cases of fetuses joined at the thoracic level. ${ }^{43}$ Prenatal sonographic evaluation of the fetal heart(s) can provide more valuable information than postnatal scans ${ }^{44}$ since the amniotic fluid is a good medium for ultrasound transmission, enhancing visualization of fetal parts. Once conjoined twins are delivered, it is difficult to place the ultrasound transducer against the small pericardial window. However, even prenatal echocardiograms may underestimate the severity of cardiac disease, as autopsy studies suggest. In particular, delineation of the relationships of the great vessels is technically demanding ${ }^{6}$ and severe cardiac malformations 
may exist even when conjoined fetuses do not share a common cardiovascular system. ${ }^{6}$

Associated anatomic anomalies are very common in conjoined fetuses, even in organ systems unrelated to the area of conjunction. Congenital diaphragmatic hernia, abdominal wall defect, neural tube defect, clubfoot, imperforate anus, esophageal atresia, and cystic hygroma, have been repeatedly reported in conjoined fetuses. In contrast, karyotype abnormalities are virtually absent in conjoined fetuses. ${ }^{18}$

\section{PLANNING PERINATAL AND POSTNATAL MANAGEMENT}

In modern obstetrics, prenatal management of conjoined fetuses has two main objectives: (a) to maximize the potential for survival of the fetuses, and (b) to minimize maternal morbidity. ${ }^{45}$ Sporadic reports in the literature have described successful vaginal delivery and subsequent survival of small conjoined twins. ${ }^{46}$ However, the method of choice for near-term delivery is cesarean section, in order to minimize maternal and neonatal birth trauma and improve neonatal survival. ${ }^{6,47,48}$ This approach also reduces the risk of uterine atony secondary to overdistension of the uterus. The obstetrician usually plans a near-term cesarean delivery after confirmation of lung maturity. In general, it is estimated that most conjoined twins are delivered prematurely, 40 percent are stillborn, and 35 percent die within the first 24 hours after delivery. ${ }^{49}$

Prenatal diagnosis of conjoined fetuses today poses a great ethical dilemma: Can this pregnancy have a favorable longterm outcome, leading to birth of human beings who after complex surgery will have normal physical, mental and psychological development and an acceptable quality of life or should such a pregnancy be terminated before reaching the stage of viability? When considering continuation of pregnancy, one has to think if modern medicine should try to correct postnatally in the operating room an "error" not timely corrected by nature with a miscarriage. As long as conjoined fetuses are in a nonviable gestational age, parents' desire, after detailed counseling about treatment options and long-term outcome, is the single most important factor regarding continuation or termination of pregnancy. After this stage however, ethical questions might be immense and emerging problems virtually impossible to be resolved. The case of Jodie and Mary, a case of conjoined twins, which gained extreme public attention five years ago, illustrates the complexity of problems arising after conjoined twins have reached the stage of viability. In this case, while medical law and ethics suggested that surgical separation was an act in favor of the twins, parents did not agree with this option. ${ }^{50}$

In our experience, we have encountered a unique case of conjoined triplets, the first case ever documented not only with prenatal ultrasound and MRI, but also with postnatal photography (Figs 3 to 8 ). ${ }^{19}$ Conjoined triplets were diagnosed

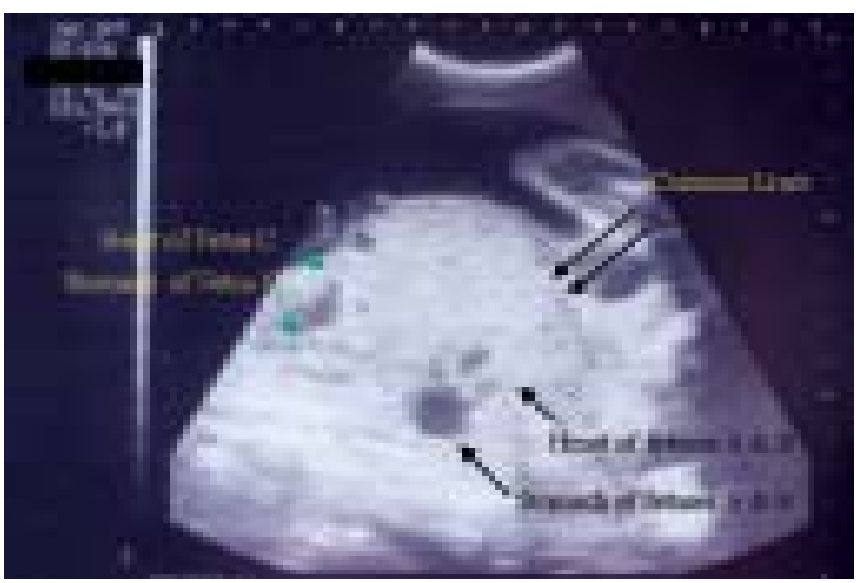

Fig. 3: Ultrasound prenatal diagnosis of conjoined triplets.A common liver, a common heart of the parapagus component and a heart (hypolastic) of the third conjoined fetus are seen. (Reprinted after authors permission from: Athanasiadis et al. A unique case of conjoined triplets. Am J Obstet Gynecol 2005;192:2084-7)

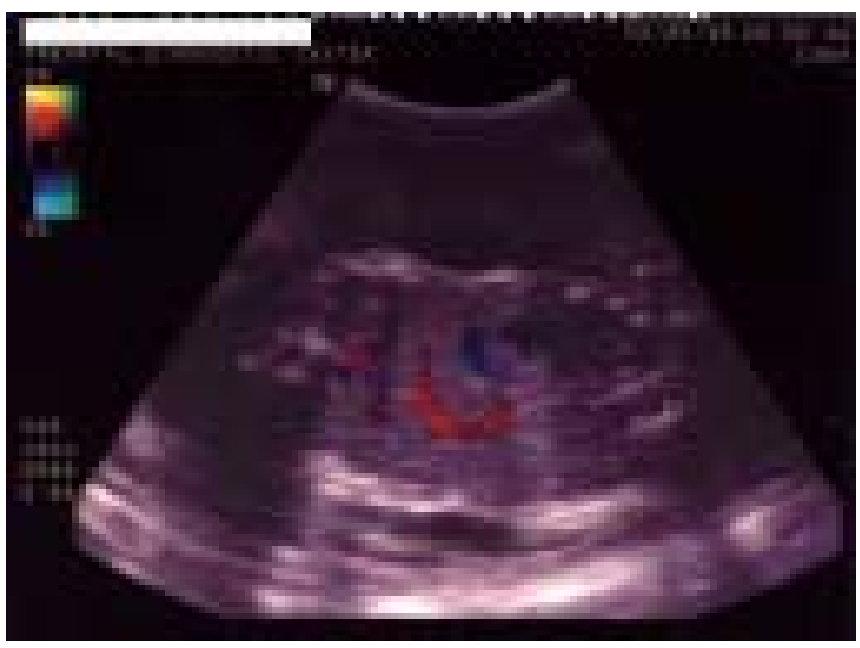

Fig. 4: Ultrasound prenatal diagnosis of conjoined triplets. A common liver and extended cardiovascular anastomoses between the conjoined fetuses are detected with the use of the color flow (Reprinted after authors permission from: Athanasiadis et al. A unique case of conjoined triplets. Am J Obstet Gynecol 2005;192:2084-7)

in the second trimester with two-dimensional ultrasound, followed by confirmation of diagnosis with MRI. In this particular case, parents opted for pregnancy termination after thorough counseling regarding further management, since both parents felt that any postnatal attempt of surgical separation would have a devastating impact in at least two or all three fetuses. The conjoined triplets were delivered at 22nd week by cesarean section, and postnatal autopsy confirmed diagnosis of tricephalus, tetrabrachius, tetrapus parapago-thoracopagus conjoined triplets. ${ }^{19}$ 


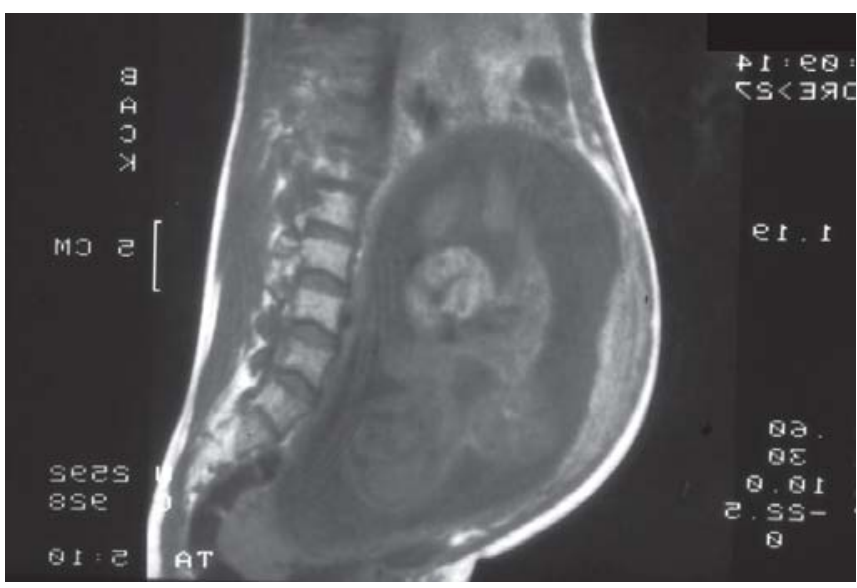

Fig. 5: Magnetic Resonance Imaging prenatal diagnosis of conjoined triplets (Reprinted after authors permission from: Athanasiadis et al. A unique case of conjoined triplets. Am J Obstet Gynecol 2005;192:20847)

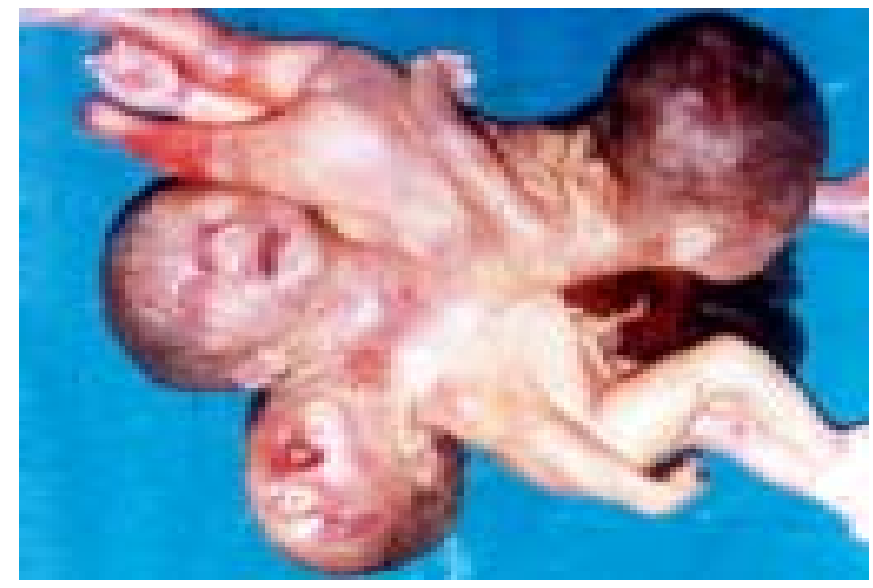

Fig. 6: A tricephalus, tetrabrachius, tetrapus, parapago-thoracopagus conjoined triplet (Reprinted after authors permission from: Athanasiadis et al. A unique case of conjoined triplets. Am J Obstet Gynecol 2005; 192:2084-7)

Successful separation of conjoined twins depends mainly on the feasibility of surgical separation of the common heart and or liver of the conjoined fetuses. Further management of conjoined twins surviving after delivery may fall into one of the three following scenarios: (a) those who die shortly after birth, (b) those who survive long enough until planned surgical separation is undertaken, and (c) those who may be saved by emergent separation at birth. ${ }^{51}$ Conjoined twins undergoing planned surgical separation have a survival rate of 80 to 90 percent in most series, ${ }^{52-54}$ compared with 30 to 50 percent survival rate in those needing emergency separation. Delayed, planned surgical separation has several advantages over emergency separation: It is associated with lower risks of anesthesia, and it allows more time to accurately reassess anatomic relationships, detect previously unrecognized

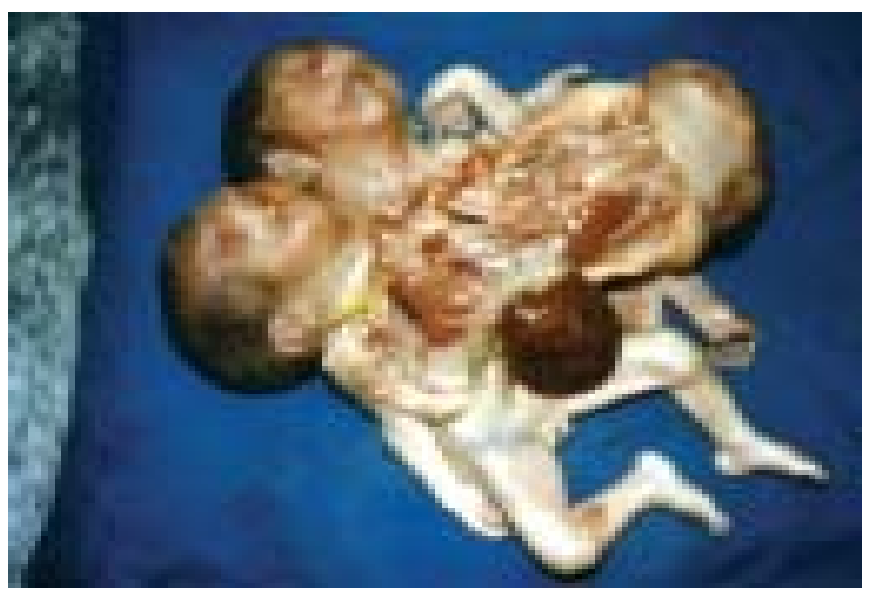

Fig. 7: A common heart and liver in parapagothoracopagus conjoined triplets (Reprinted after authors permission from: Athanasiadis et al. A unique case of conjoined triplets. Am J Obstet Gynecol 2005; 192: 2084-7)

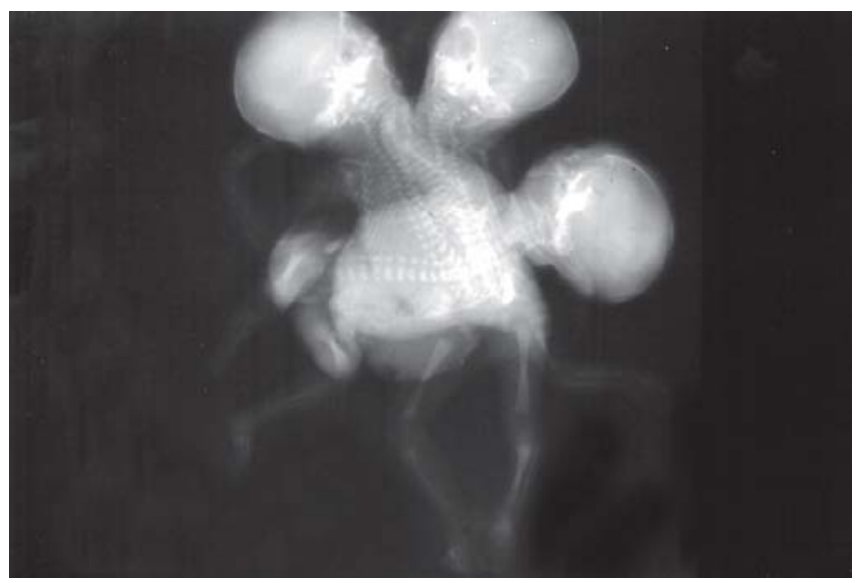

Fig. 8: Conjoined triplets. Three distinct spines and heads. A postmortem plain X-ray (Reprinted after authors permission from: Athanasiadis et al. A unique case of conjoined triplets. Am J Obstet Gynecol 2005;192: 2084-7)

congenital anomalies, and make plans to ensure adequate wound coverage. $^{18}$

In our experience, planned postnatal surgical separation led to favorable outcomes in two cases, a case of omphalopagus and a case of craniopagus conjoined twins (Figs 9 to 12 ). ${ }^{55}$ In the case of omphalopagus twins, cardiac anomalies were detected prenatally in only one of the twins, but there were no signs of shared cardiac structures, making continuation of pregnancy to a viable stage reasonable, since successful postnatal surgical separation was possible. In the case of craniopagus twins, the absence of prenatal sonographic signs of shared neural tissue showed that postnatal surgical separation might be successful as well. ${ }^{55}$

Detailed prenatal counseling of parents is crucial in decisionmaking with regard to continuation of pregnancy and planning 


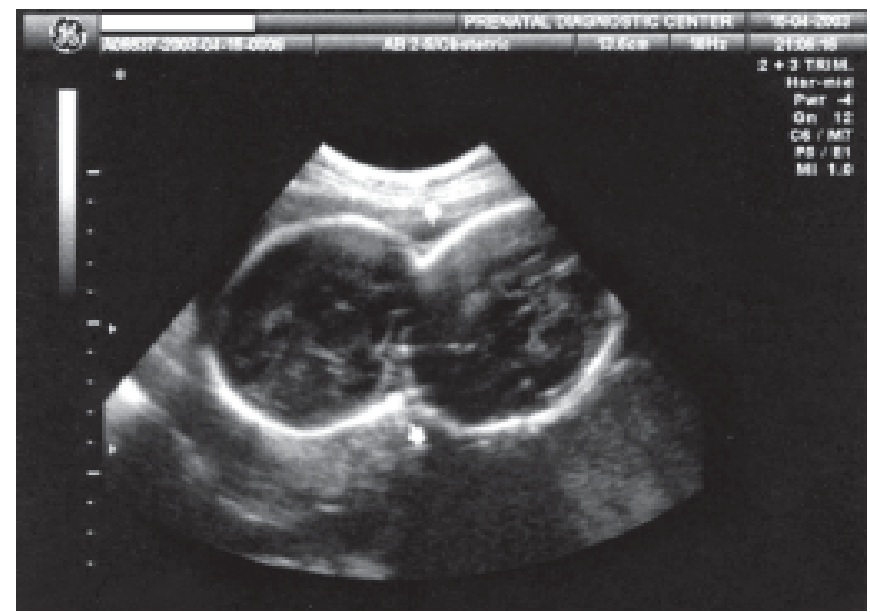

Fig. 9: Prenatal diagnosis of cephalopagus conjoined twins with twodimensional ultrasound. The arrows show the level of conjunction (Reprinted after authors permission from: Athanasiadis et al. Prenatal management and postnatal separation of omphalopagus and craniopagus conjoined twins. Gynecol Obstet Invest; in press)

postnatal management. An interdisciplinary medical team, involving obstetricians, neonatologists, pediatric surgeons and anesthetists, should undertake counseling. ${ }^{55}$ In special cases, additional consultation may be given by other specialists, even from specialized centers in other countries, depending on the area of conjunction, the involvement of other organ systems, and the presence of associated anomalies. In the case of craniopagus twins described above, parents received additional, prenatal consultation from a specialized neurosurgical center in Italy, and the twins were finally separated postnatally at the same center. ${ }^{56}$

Obstetricians play a pivotal role in coordinating meetings between parents and members of the interdisciplinary medical team. ${ }^{55}$ Counseling should include detailed sessions regarding the rarity and unclear etiology of this condition, as well as information about the anatomic structures involved in the area of conjunction, and associated or coincidental anomalies. Parents should be informed that there are no known inheritance patterns or contributing environmental factors. Furthermore, adequate time should be given to parents in order to discuss the options of surgical separation, prognosis for every fetus after surgery, long-term sequelae, cosmetic issues, and quality of life in childhood and adult life. A very important issue is to preserve privacy of the parents, in order to avoid additional psychological distress, by keeping media and unwanted visitors or even relatives in a distance. Unfortunately, conjoined gestations attract the attention of the general public, and this may occasionally evolve to malicious publicity. The media, by aiming to report sharp and breath-taking stories, do not hesitate to report the birth of such unusual neonates without considering the social and ethical consequences this may have to the whole

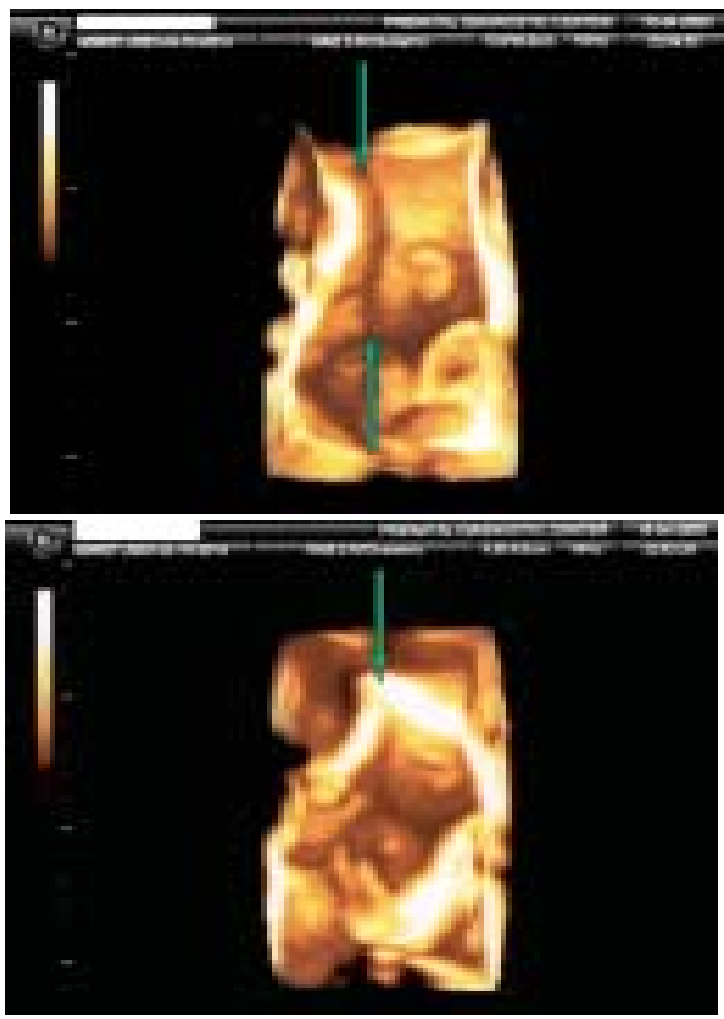

Figs 10 and 11: Prenatal diagnosis of cephalopagus conjoined twins with three-dimensional ultrasound. The green arrows show the level of conjunction (Reprinted after authors permission from: Athanasiadis et al. Prenatal management and postnatal separation of omphalopagus and craniopagus conjoined twins. Gynecol Obstet Invest; in press)

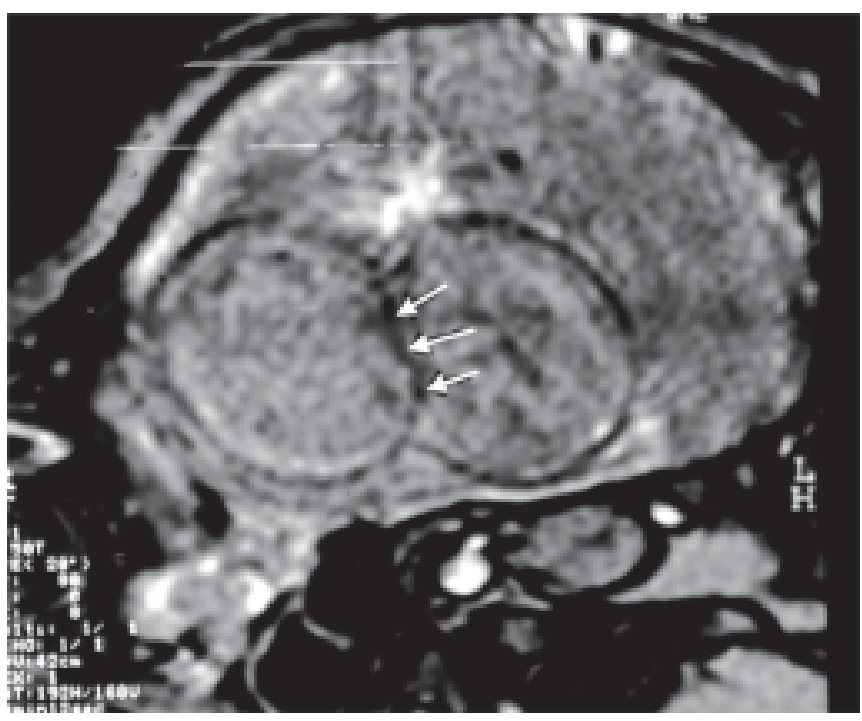

Fig. 12: Prenatal diagnosis of cephalopagus conjoined twins with Magnetic Resonance Imaging. The arrows show the level of conjunction (Reprinted after authors permission from: Athanasiadis et al. Prenatal management and postnatal separation of omphalopagus and craniopagus conjoined twins. Gynecol Obstet Invest; in press) 
family. Some doctors and paramedical personnel involved in the pre- and postnatal management of conjoined fetuses are potential sources of information to journalists; anyone would agree that it is not ethically appropriate to give details to the press without parental permission. Parents are going through a stressful ordeal, facing devastating ethical dilemmas, and this makes respect, discretion, and compassion from all sides imperative. ${ }^{55}$

\section{CONCLUDING REMARKS}

Conjoined fetuses are very rarely seen in human pregnancies. Etiopathogenesis is unclear, without any known inciting factor(s) leading to this condition. There are two opposing theories, supporting fission versus fusion of embryos in the early first trimester. Prenatal diagnosis and accurate recognition of shared organs between fetuses are essential in order to decide for or against continuation of pregnancy, and plan prenatal surveillance and postnatal management. Cesarean section is the preferable mode of delivery. Obstetricians play a pivotal role in prenatal counseling, and in coordinating meetings between parents and members of the interdisciplinary medical team needed in the management of such complex cases.

\section{REFERENCES}

1. Guttmacher AF. Biographical notes on some famous conjoined twins. Birth Defects 1967;3:10-17.

2. van den Brand SFJJ, Nijhuis JG, van Dongen PWJ. Prenatal ultrasound diagnosis of conjoined twins. Obstet Gynecol Survey 1994;49:656-62.

3. Harper RG, Kenigsberg K, Sia CG, Horn D, Stern D, Bongiovi V. Xiphopagus conjoined twins: a 300-year review of the obstetric, morphopathologic, neonatal, and surgical parameters. Am J Obstet Gynecol 1980;137:617-29.

4. Hansmann M, Schlachter H, Foedisch HJ, et al. Prapartale Diagnose eines Thoracopagus mittels Ultrasonographie. Gynakologe 1979;12:64.

5. Gray CH, Nix HG, Wallace AJ. Thoracopagus twins: prenatal diagnosis. Radiology 1950;54:398.

6. Barth RA, Filly RA, Goldberg J, Moore P, Silverman NH. Conjoined twins: prenatal diagnosis and assessment of associated malformations. Radiology 1990;177:201-7.

7. Wilson RL, Cetrulo CL, Shaub MS. The prepartum diagnosis of conjoined twins by the use of diagnostic ultrasound. Am J Obstet Gynecol 1976;126:737.

8. Fagan CJ. Antepartum diagnosis of conjoined twins by ultrasonography. Am J Roentgenol 1977;129:921-2.

9. Morgan CL, Trought WS, Sheldon G, Barton TK. B-scan and realtime ultrasound in the antepartum diagnosis of conjoined twins and pericardial effusion. Am J Roentgenol 1978;130:57880 .

10. Wood MJ, Thompson HE, Roberson FM. Realtime ultrasound diagnosis of conjoined twins. J Clin Ultrasound 1981;9:195-7.
11. Schmidt W, Heberling D, Kubil F. Antepartum ultrasonographic diagnosis of conjoined twins in early pregnancy. Am J Obstet Gynecol 1981;139:961-3.

12. Schmidt W, Kubli F. Early diagnosis of severe congenital malformations by ultrasonography. J Perinat Med 1982;10:23341.

13. Skupski DW, Streltzoff J, Hutsen M, Rosenwaks Z, Cohen J, Chervenak FA. Early diagnosis of conjoined twins in triplet pregnancy after in vitro fertilization and assisted hatching. J Ultrasound Med 1995;14:611-5.

14. Hill LM. The sonographic detection of early first-trimester conjoined twins. Prenatal Diagnosis 1997;17:961-3.

15. Lam YH, Sin SY, Lam C, Lee CP, Tang MHY, Tse HY. Prenatal sonographic diagnosis of conjoined twins in the first trimester: two case reports. Ultrasound Obstet Gynecol 1998;11:289-91.

16. Goldberg Y, Ben-Shlomo I, Weiner E, Shalev E. First trimester diagnosis of conjoined twins in a triplet pregnancy after IVF and ICSI: case report. Hum Reprod 2000;15:1413-5.

17. Daskalakis G, Pilalis A, Tourikis I, Moulopoulos G, Karamoutzos I, Antsaklis A. First trimester diagnosis of dicephalus conjoined twins. Eur J Obstet Gynecol Reprod Biol 2004;112:110-13.

18. Mackenzie TC, Crombleholme TM, Johnson MP, Schnaufer L, Flake AW, Hedrick HL, Howell LJ, and Adzick NS. The natural history of prenatally diagnosed conjoined twins. J Pediatr Surg 2002;37:303-9.

19. Athanasiadis AP, Tzannatos C, Mikos T, Zafrakas M, Bontis J. A unique case of conjoined triplets. Am J Obstet Gynecol 2005;192:2084-7.

20. Tan KL, Tock EPC, Dawood MY, Ratnam SS. Conjoined twins in a triplet pregnancy. Am J Dis Child 1971;122:455-8.

21. Sepulveda W, Munoz H, Alcalde JL. Conjoined twins in a triplet pregnancy: early prenatal diagnosis with three-dimensional ultrasound and review of the literature. Ultrasound Obstet Gynecol 2003;22:199-204.

22. Hanson JW. Incidence of conjoined twinning. Lancet 1975;2:1257.

23. Edmonds LD, Layde PM. Conjoined twins in the United States 1970-1977. Teratology 1982;25:301-8.

24. Viljoen DL, Nelson MM, Beighton P. The epidemiology of conjoined twinning in Southern Africa. Clin Genet 1983;24:1521.

25. Spencer R. Theoretical and analytical embryology of conjoined twins: part I: Embryogenesis. Clin Anat 2000;13:36-53.

26. Apuzzio JJ, Ganesh V, Landau I, Pelosi M. Prenatal diagnosis of conjoined twins. Am J Obstet Gynecol 1984;148:343-4.

27. Zeng SM, Yankowitz J, Murray JC. Conjoined twins in a monozygotic triplet pregnancy: prenatal diagnosis and X-inactivation. Teratology 2002;66:278-81.

28. Steinman G. Mechanisms of twinning. V. Conjoined twins, stem cells and the calcium model. J Reprod Med 2002;47:313-21.

29. Alikani M, Noyes N, Cohen J, Rosenwaks Z. Monozygotic twinning in human is associated with zona pellucida architecture. Hum Reprod 1994;9:1318-21.

30. Edwards RG, Mettler L, Walter DE. Identical twins and in vitro fertilization. J In Vitro Fertil Embryo Tranfer 1986;3:114-7. 
31. Pajkrt E, Jauniaux E. First-trimester diagnosis of conjoined twins. Prenat Diagn 2005;25:820-6.

32. Chatterjee MS, Weiss RR, Verma UL, Tejani NA, Macri J. Prenatal diagnosis of conjoined twins. Prenat Diagn 1983;3:35761.

33. Hubinont C, Pratola D, Rotschild E, Rodesch F, Schwers J. Dicephalus: unusual case of conjoined twins and its prepartum diagnosis. Am J Obstet Gynecol 1984;149:693-4.

34. Kalchbrenner M, Weiner S, Templeton J, Losure TA. Prenatal ultrasound diagnosis of thoracopagus conjoined twins. J Clin Ultrasound 1987;15:59-63.

35. MacKenzie AP, Stephenson CD, Funai EF, Lee MJ, TimorTritsch I. Three-dimensional ultrasound to differentiate epigastric heteropagus conjoined twins from a TRAP sequence. Am J Obstet Gynecol 2004;191:1736-9.

36. Blum E, Pearlman M, Graham D. Early second-trimester sonographic diagnosis of thoracopagus twins. J Clin Ultrasound 1986;14:207-8.

37. Scharl A, Schlensker KH, Wohlers W, Heymans L. Fruhe Ultraschall-diagnose des Thorakopagus. Z Geburtshilfe Perinatol 1988;192:38-41.

38. Filler RM. Conjoined twins and their separation. Semin Perinatol 1986;10:82-91.

39. Iura T, Makinoda S, Sasakura C, Hirosaki N, Inoue H, Waseda $\mathrm{T}$, Watanabe Y. Hemodynamic analysis of cephalothoracopagus by the color Doppler method. A comparison to normal fetuses via a longitudinal study. Fetal Diagn Ther 2006;21:61-4.

40. Razavi-Encha F, Mulliez N, Benhaiem-Sigaux N, Gonzales M, Casasoprana A, Bloch G, Roux C. Cardiovascular abnormalities in thoracopagus twins: embryological interpretation and review. Early Hum Dev 1987;15:33-44.

41. Kaplan M, Glaser J, Eidelman AJ. Early cardiac evaluation of thoracically conjoined twins. Cardiology 1983;70:152-5.

42. Synhorst D, Matlak M, Roan Y, Johnson D, Byrne J, McGough E. Separation of conjoined thoracopagus twins joined at the right atria. Am J Cardiol 1979;43:662-5.

43. Andrews RE, McMahon CJ, Yates RW, Cullen S, de Leval MR, Kiely EM, Spitz L, Sullivan ID. Echocardiographic assessment of conjoined twins. Heart 2006;92:382-7.
44. Sanders SP, Chin AJ, Parness IA, Benacerraf B, Greene MF, Epstein MF, Colan SD, Frigoletto FD. Prenatal diagnosis of congenital heart defects in thoracoabdominally conjoined twins. N Engl J Med 1985;313:370-4.

45. Bianchi DW, Crombleholme TM, D’Alton ME (Eds); Fetology - The diagnosis and management of the fetal patient: Conjoined twins. McGraw-Hill: New York 2000; 892-99.

46. Jing G, Yun-feng G. Prenatal diagnosis of conjoined twins wiht real-time ultrasound. Clin Med J 1988;101:58.

47. Vaughn TC, Powel LC. The obstetrical management of conjoined twins. Obstet Gynecol 1979;53:67S-72S.

48. Hammond DI, Okun NB, Carpenter BF, Martin DJ, Krzaniak S. Prenatal Ultrasonographic diagnosis of dicephalus conjoined twins. Can Assoc Radiol J 1991;42:357-9.

49. Sakala EP. Obstetric management of conjoined twins. Obstet Gynecol 1986;67:S21-25.

50. Pearn J. Bioethical issues in caring for conjoined twins and their parents. Lancet 2001;357:1968-71.

51. Graivier L, Jacoby MD. Emergency separation of newborn conjoined (Siamese) twins. Tex Med 1980;76:60-2.

52. O’Neill JA Jr, Holcomb GW 3rd, Schnaufer L, Templeton JM Jr, Bishop HC, Ross AJ 3rd, Duckett JW, Norwood WI, Ziegler MM, Koop CE. Surgical experience with thirteen conjoined twins. Ann Surg 1988;208:299-312.

53. Chiu CT, Hou SH, Lai HS, et al. Separation of thoracopagus conjoined twins. A case report. J Cardiovasc Surg (Torino) 1994;35:459-62.

54. Spitz L, Kiely E. Success rate for surgery of conjoined twins. Lancet 2000;356:1765.

55. Athanasiadis A, Mikos T, Zafrakas M, Diamanti V, Papouli M, Assimakopoulos E, Pados G, Tzevelekis F, Bontis J. Prenatal management and postnatal separation of omphalopagus and craniopagus conjoined twins (Submitted for publication).

56. Di Rocco C, Caldarelli M, Tamburrini G, Koutzoglou M, Massimi L, Di Rocco F, Sabatino G, Farallo E, Seccia A, Pietrini D, Valenti M, Forte E, Rollo M, Tartaglione T, Pedicelli A, Tortorolo L, Piastra M. Craniopagus: the Thessaloniki-Rome experience. Childs Nerv Syst 2004;20:576-86. 